\title{
EDITORIAL
}

\section{AL DR. JOHN VÍCTOR MURRA, COSMOPOLITA VETERANO DE LUCHAS INTELECTUALES Y POLÍTICAS DEL SIGLO VEINTE}

\author{
FOR DR. JOHN V. MURRA COSMOPOLITAN VETERAN \\ OF THE STRUGGLES OF THE TWENTIETH CENTURY
}

\author{
Tristan Platt ${ }^{1}$, Victoria Castro ${ }^{2}$, Frank Salomon ${ }^{3}$, Jorge Hidalgo ${ }^{4}$, Lautaro Núñez ${ }^{5}$, \\ Carlos Aldunate del Solar ${ }^{6}$,Vivien G. Standen ${ }^{7}$ y Calogero Santoro ${ }^{8}$
}

Pocos días después del fallecimiento del Dr. Murra, hacia fines del año 2006, los colegas Victoria Castro, Carlos Aldunate, Jorge Hidalgo, Lautaro Núñez y Calogero Santoro comenzamos a conversar en Chile la necesidad de convocar un número de Chungara Revista de Antropología Chilena, para conmemorar a este gran y apreciado maestro, una figura tan fundamental como controversial en la historia de los estudios andinos. De estas conversaciones también tomaron parte activa Tristan Platt y Frank Salomon, quienes, a su vez, nos hicieron saber de la conmemoración realizada en l'École des Hautes Études en Sciences Sociales (CERMA), París, en enero de 2007, y del "Acto de Homenaje a John V. Murra" organizado en febrero de 2007, por el Institut Català d'Antropologia de Barcelona, cuyos manuscritos conmemorativos se incluyen en este número de Chungara. A continuación de esta Editorial se añade la presentación de Verena Stolcke en la conmemoración de Barcelona.

El Dr. Murra tuvo una importante relación e influencia en Chile y, en particular, con la Universidad de Tarapacá, a tal punto que en algunos momentos de su vida pensó radicarse en Arica; pero lo mismo dijo con respecto a Buenos Aires, Sucre, Barcelona o París de acuerdo a sus propios comentarios y lo señalado por Thérèse Bouysse-Cassagne o Ana María Presta. Desde
In the days following Dr Murra's death in October 2006, Victoria Castro, Carlos Aldunate, Jorge Hidalgo, Lautaro Núñez and Calogero Santoro began to discuss in Chile the idea of publishing a number of Chungara Revista de Antropologia Chilena, in memory of our great and beloved master, a fundamental and controversial figure in the history of Andean Studies. An active part in these conversations was taken by Tristan Platt and Frank Salomon, who in turn informed us of the commemoration organized in the École des Hautes Études en Sciences Sociales (CERMA), Paris, in January 2007, and the "Act of Homage to John V. Murra" celebrated in February 2007 by the Institut Català d'Antropologia of Barcelona. It was agreed to include the speeches delivered in Barcelona in this number of Chungara. A presentation by Verena Stolcke of the meeting in Barcelona follows this Editorial.

Dr Murra had an important relation with Chile, where he exercised considerable influence, especially in the University of Tarapacá, and he even considered retirement in Arica; although he also thought of Buenos Aires, Sucre, Barcelona or Paris, as mentioned by Thérèse Bouysse-Cassagne and Ana María Presta. From the beginning of the 1970s, he visited what was then the University of the North (Arica), seeking a few of those he called his

\footnotetext{
School of Philosophical, Anthropological and Film Studies, University of St. Andrews, St. Andrews, Scotland. tp@ st-andrews.ac.uk. Departamento de Antropología, Facultad de Ciencias Sociales, Universidad de Chile. Las Perdices 575, La Reina, Santiago, Chile.vcastrorojas@hotmail.com

John V. Murra Professor of Anthropology, University of Wisconsin, Wisconsin, EE.UU. fsalomon@ wisc.edu Departamento de Ciencias Históricas, Facultad de Filosofía y Humanidades, Universidad de Chile, Santiago, Chile. hidalgol@uchile.cl

5 Instituto de Investigaciones Arqueológicas y Museo, Universidad Católica del Norte, San Pedro de Atacama, Chile. lautaro.nunez@hotmail.com

Museo Chileno de Arte Precolombino, Bandera 361, Santiago, Chile. caldunate@ museoprecolombino.cl Departamento de Antropología, Universidad de Tarapacá, Casilla 6-D, Arica, Chile. vivien.standen@gmail.com Instituto Alta Investigación, Departamento Antropología, Universidad Tarapacá, Arica, Chile, Centro de Investigaciones del Hombre en el Desierto, Arica, Chile. calogero_santoro@yahoo.com.
} 
comienzos de los años setenta del siglo veinte visitó la Universidad del Norte, buscando a los que le gustaba llamar "colegas" como Tristan Platt, Jorge Hidalgo y Nancy Alanoca y otros personajes aymara unidos por un interés común, lo andino. Hacia fines de los años noventa envió parte de su colección andina a la Universidad de Tarapacá, en cuya biblioteca de Antropología en el Campus Azapa, es posible identificar su típica firma en la esquina superior derecha de las primeras păginas de sus libros y revistas.

Fue, sin embargo, en Perú donde desarrolló y publicó gran parte de su trabajo intelectual, pero su misión andina se fundó en Ecuador a comienzos de los años cuarenta, lo que quedó inmortalizado en una clásica foto de Murra montado a caballo en un pajonal de la sierra ecuatoriana (Salomon 2010). De allí que las visitas a Arica formaran parte de interminables periplos por distintos lugares de Perú, Bolivia y Argentina a donde llegaba con su misión andina; un plan académico-populista de su propia invención, creado como una manera de reemplazar su primera misión de guerrerotraductor de España, que lo convirtió en un gran sensibilizador político, que daba esperanza a la gente, algo en que creer, como él mismo decía y este mensaje de volcarse a "lo andino" como una forma de vida convenció y entusiasmó a muchos (Flores Ochoa 2010; Platt 2010).

Su admiración por José María Arguedas, sin embargo, muestra una faceta distinta de esta misión, en la medida que reconocía que Arguedas entregaba una visión más general y humanista sobre lo andino desde el mundo de las letras y no de la antropología propiamente tal. Murra reconoció a Arguedas como un "poeta" desde cuya trinchera "pudo hacer cosas que yo no puedo hacer", decía, como escribir su prosa en quechua que debió transmutar nefastamente al castellano. La devoción de Murra por Arguedas (Platt 2010; Salomon 2010) lo llevó no sólo a defenderlo sino a ponerlo de ejemplo en las arenas académicas más elevadas y señalar que su táctica era tan válida como las tácticas antropológicas, intentando romper la mirada estrecha de la disciplina (Murra 1998).

Convinimos que el concepto de este homenaje no sería una Festschrift en el sentido común de la palabra, sino una antología de ensayos que evocaran y conmemoraran la importancia, profundidad e influencia de las ideas del Dr. Murra en el desarrollo de las ciencias antropológicas e históricas dentro y fuera de los Andes. También esperábamos narraciones "colleagues", such as Tristan Platt, Jorge Hidalgo and Nancy Alanoca, as well as other Aymaras, all united by a common interest in Andean things. Towards the end of the 1990s he sent part of his Andean library to the University of Tarapacá, and in the Anthropology Library of the Azapa campus his distinctive signature $\mathcal{L}$. be identified in the top right-hand corner of the first pages of his books and periodicals.

It was in Peru that he worked on and published a major part of his intellectual output, following earlier visits to Ecuador where he began to develop his Andean mission. Hence his visits to Arica formed part of his interminable journeys to different parts of Peru, Ecuador, Bolivia, Chile and Argentina, following an academic-populist project of his own invention, which was intended in part to substitute for his earlier mission as soldier-interpreter in the Spanish Civil War. He became a great political sensitizer, giving hope to people, something in which to believe (as he said himself), and his example of dedication to Andean things convinced and enthused his many followers (Flores Ochoa 2010; Platt 2010).

His admiration for José María Arguedas shows a different aspect of his mission, for he recognised in Arguedas a more general, humanist vision of the Andes, expressed from the wider world of letters and not specifically from anthropology. Murra saw in Arguedas "a poet, who could do things I can't do", such as write in Quechua which had then to be translated - very approximately - into Spanish. Murra's devotion to Arguedas (Platt 2010; Salomon 2010) led him not only to defend him, but to make him an example in the highest academic spheres. He argued that Arguedas' "tactic" was as valid as any anthropological approach, thereby breaking with the narrowness of a purely academic perspective (Murra 1998).

We agreed that this special number of Chungara should not be a Festschrift in the usual sense of the word, but rather an anthology of essays that would evoke and celebrate the importance, profundity and influence of Dr Murra's ideas within and beyond the Andes. We also hoped for free narratives that might re-create his transcendence in the lives of those who knew him and enjoyed his company, whether in person or as correspondent.

Since our first invitations went out, more time has passed than we expected, which has allowed us to compile and integrate a wide spectrum of 
más libres que revivieran su trascendencia en las vidas de quienes le conocieron y disfrutaron de su compañía presencial y epistolar.

Desde la primera convocatoria ha pasado más tiempo del esperado, lo que permitió, sin embargo, compilar e integrar un amplio espectro de visiones y perspectivas respecto de la "residencia del Dr. Murra en la tierra", parafraseando el título de uno de los libros de Pablo Neruda, de escritura profunda, "hermética", insurgente según algunos, como fue en cierta forma la vida de nuestro homenajeado.

A esto se agrega su interminable trashumancia por el mundo que inicia, de alguna manera, con su partida de Odesa al sur de Ucrania de la mano de su madre, a muy corta edad como indica al inicio de su relato Olivia Harris $\dagger$ (Albó y Bubba 2009; BouysseCassagne y Platt 2009; Harris 2010). Detalles de éste y otros aspectos de la vida cosmopolita del Dr. Murra, que lo llevaron a los más recónditos rincones del planeta, son relatados sentidamente por todos los colegas que lo conocieron en distintas épocas y lugares y que muestran de otra manera también su carácter de permanente inmigrante.

Consecuentemente, el número contiene una pléyade de manuscritos y testimonios provenientes de Sudamérica, Europa y Estados Unidos que reflejan muy bien la internacionalidad de su movimiento académico andinista. Salvo algunas excepciones, casi todos se redactaron o tradujeron al castellano, el idioma de la contingencia, "aprendido en la guerra", como decía el Dr. Murra, y en el que prefirió escribir la mayor parte de su creación etnológica, aunque manejara con igual maestría el francés y el inglés que usó para algunas de sus publicaciones, otra faceta más de su cosmopolitismo. La convocatoria sirvió también para rescatar antiguos amigos, como Verónica Cereceda de quien el Dr. Murra tenía siempre muy buenos recuerdos desde sus épocas en Iquique, Lima, París y Bolivia, junto a Gabriel Martínez, o Ana María Lorandi a quien le reconocía un importante aporte a la discusión de su modelo clásico de verticalidad en los años setenta (Lorandi 2010), o Sidney Mintz quien fue el primero en enviar su remembranza, desde Estados Unidos, o Nicolás Sánchez-Albornoz (2010) quien hila la vida cosmopolita del Dr. Murra en torno a la Guerra Civil española y cómo de su experiencia como brigadista internacional nació su estimación por el pueblo español.

La sección In Memoriam contiene veintidós testimonios con vívidos detalles de su personalidad perspectives on the "residence of Dr Murra on earth". With this we paraphrase the title of one of Pablo Neruda's books, considered by many a deep, "hermetic" and insurgent text, as was, in many respects, the life of our master.

To this must be added his interminable transhumance which began with his departure, at a very young age, from Odessa in southern Ukraine, hand in hand with his mother, as Olivia Harris indicates at the beginning of her account (Albó and Bubba 2009; Bouysse-Cassagne and Platt 2009). Details of this and other aspects of Dr Murra's cosmopolitan life, which took him to the remotest parts of the planet, are told with feeling by many colleagues who knew him in different times and places, revealing his character as a permanent migrant.

This number of Chungara therefore contains a range of manuscripts and testimonies from Europe, the United States and South America, which reflect the international nature of his Andeanist academic movement. All have been written or translated into Spanish, the language of necessity, "learned in the War" as Dr Murra put it, and in which he preferred to write most of his ethnological work, although he was equally skilled in French and English which he used on other occasions, according to the needs of his cosmopolitan life. Our invitation also served to recover some old friends, such as Veronica Cereceda, of whom Dr Murra always had the warmest memories from his times in Iquique, Lima, Paris and Bolivia, together with Gabriel Martinez; or Ana María Lorandi whom he recognised as having made an important contribution to the discussion of his classic model of "verticality" in the 1970s (Lorande 2010); or Sidney Mintz, who was the first to send his memorial from the United States; or Nicolás Sánchez-Albornoz (2010) who tells of Dr Murra's life in the Spanish War, in which he was part of the international brigades, an experience which left him with a lasting affection for the people of Spain.

The In Memoriam section contains twenty-two testimonies with vivid details of his personality and specific circumstances of his long, complex and intense life, guided by his personal and political experiences, and expressed through his seductive cosmopolitan character: a veteran of the struggles of the twentieth century, constant creator of academic networks, friend of the Quechua and Aymaraspeaking peoples, knowledgeable cultivator of the 
y de circunstancias específicas de su larga, compleja e intensa vida, guiada por su vivencia personal y política, mediatizada por su seductor carácter cosmopolita, veterano de las luchas del siglo veinte, creador permanente de redes académicas, amigo de los pueblos quechua y aymara hablantes, conocedor y cultivador del mundo de las letras, a lo que se agrega un listado exhaustivo de sus obras publicadas.

La sección Artículos integra catorce estudios antropológicos, etnohistóricos y arqueológicos. Estos ensayos son un testimonio de la fecundidad y del amplio espectro de influencias de su pensamiento, que trascendió el área andina alcanzando la antropología occidental de la segunda mitad del siglo veinte, en general.

Parafraseando a Lautaro Núñez y Tom Dillehay, Murra fue un gran eje giratorio que articuló gente e instituciones de los más apartados lugares del planeta, o como señala, con voz bajita Verónica Cereceda (2010) Quizás no hay ya nadie como él hoy, tan dedicado a impulsar los estudios andinos no sólo siendo un lector atento, sino a través de gestiones, cartas, publicaciones, que él se daba la molestia de llevar adelante para desarrollar los trabajos de otros colegas. Muchos somos los que estamos en deuda con su pasión y su amistad calurosa. Sidney Mintz (2010), quien lo conoció durante largos años tuvo la oportunidad de escucharlo en lo que fue tal vez su último discurso público, en la embajada de Suiza en Washington DC en el 2002, en la conmemoración de los 100 años de Alfred Métraux. A pesar de sus limitaciones físicas renovó su poderío de orador fascinante, cautivador y su vocación por el poder, el poder de influir y de avanzar en la causa de una vida humana más justa, atrincherado en la única colectividad que lo identificaba, la antropología, en la cual, como señala Olivia Harris (2010), "encontraba una casa, una familia global de la cual le gustaba formar parte".

Esta edición está patrocinada por el Institute of Andean Research de New York, institución a la cual, el Dr. Murra perteneció por varios años, por la Universidad de Tarapacá de Arica, Chile, y por el Centro de Investigaciones del Hombre en el Desierto, Arica, Chile. world of letters. An exhaustive bibliography of his writings is included.

The Articles section, on the other hand, contains fourteen anthropological, ethnohistorical and archaeological studies. These essays are a testimony of the fecundity and broad influence of his thought, which transcended the Andean area and contributed to Western anthropology generally in the second half of the twentieth century.

In the words of Lautaro Núñez and Tom Dillehay, Murra was a great gyrating axis who articulated people and institutions in distant parts of the world, or as Veronica Cereceda gently suggests (2010): "Perhaps there is no one like him today, so dedicated to promoting Andean studies, not only as an attentive reader, but through recommendations, letters, publications, in which he took the trouble to help and promote the work of other colleagues. Many of us are in his debt for his passion and the warmth of friendship". Sidney Mintz (2010), who knew him for many long years, had the opportunity of hearing him in what was perhaps his last public address, in the Swiss Embassy in Washington DC in 2002, during the centenary commemoration of Alfred Métraux. In spite of his physical limitations, he recovered his power as a fascinating and captivating orator, and his vocation for power, the power to influence and advance the cause of a more just life for humanity, speaking as a member of the only collectivity with which he identified, anthropology, in which, as Olivia Harris indicates (2010), "he found a home, a global family to which he felt he belonged".

This publication has been sponsored by the Institute of Andean Research of New York, institution to which Dr. Murra belonged for several years; by the University of Tarapaca, Arica; and by the Centre for the Investigation of Man in the Desert, Arica, Chile. 